\title{
Application of Taguchi Grey Analysis to Optimization of Mechanical Properties of ZrWN/buffer Multilayer Coatings
}

\author{
Yong-Chang Zhao ${ }^{1}$, Ding-Yeng Chen ${ }^{2}$, Ding-Chiang Hü ${ }^{3}$, Jian-Rong Li ${ }^{4, *}$, Chun-Yao Hsu ${ }^{3, *}$ \\ ${ }^{1}$ School of Engineering Technology, Jiangsu Institute of Commerce, Jiangsu, China \\ ${ }^{2}$ Department of Mechanical Engineering, Hwa Hsia University of Technology, New Taipei City, \\ Taiwan \\ ${ }^{3}$ Department of Mechanical Engineering, Lunghwa University of Science and Technology, Taoyuan \\ 33306, Taiwan \\ ${ }^{4}$ College of Electric and IT, Yangzhou Polytechnic Institute, Jiangsu, 225127, China \\ *E-mail: $11083398 @ q q . c o m(J .-R ~ L i)$, cyhsu@mail.lhu.edu.tw (C.-Y. Hsu)
}

doi: $10.20964 / 2019.05 .22$

Received: 22 December 2018 / Accepted: 19 February 2019 / Published: 10 April 2019

\begin{abstract}
Zirconium tungsten nitride (ZrWN) films are deposited onto SUS 304 stainless steel and glass, with and without a tungsten (W) and tungsten nitride (WN) buffer layer, by means of direct current (DC) reactive magnetron sputtering. This study determines the optimal parameter settings for the multilayer (ZrWN/buffer) deposition process using the Taguchi method for the design of a robust experiment and grey relational analysis. An orthogonal array, the signal-to-noise ratio and an analysis of variance are used to determine the effect of the deposition parameters. The main deposition parameters for the buffer layer, such as the W DC power, the substrate bias, the $\mathrm{N}_{2} /\left(\mathrm{N}_{2}+\mathrm{Ar}\right)$ flow rate, the substrate temperature, are optimized, with reference to the structure, morphological and mechanical properties of the multilayer (ZrWN/buffer) coating. The results show that the buffer layer improves the performance of ZrWN films. The $\mathrm{N}_{2} /\left(\mathrm{N}_{2}+\mathrm{Ar}\right)$ flow rate and the W DC power have the most significant effect on the mechanical performance. A Taguchi grey analysis shows that the coefficient of friction is reduced from 0.55 to 0.52 , the corrosion potential increases from -0.18 to $-0.16 \mathrm{~V}$ and the Vickers hardness increases from 13.44 to $17.65 \mathrm{GPa}$. The multilayer coatings exhibit no cracking or peeling-off, are homogeneous and highly dense and have a smooth surface and a very compact structure. They adhere well to the substrate and the indentation samples are classified as HF1.
\end{abstract}

Keywords: buffer layer; sputtering; Taguchi grey; mechanical properties.

\section{$\underline{\text { FULL TEXT }}$}


(C) 2019 The Authors. Published by ESG (www.electrochemsci.org). This article is an open access article distributed under the terms and conditions of the Creative Commons Attribution license (http://creativecommons.org/licenses/by/4.0/). 